\title{
Myotatic Irritability
}

\author{
BY W. T. C. BERRY \\ Ministry of Health, 23 Savile Row, London, W. I \\ (Received 25 November 1953)
}

The synonyms myotatic irritability, myoidema, and Schiff's wave, are applied to a response of muscle to firm tactile stimulus. The response is limited to the area of stimulation, and consists of a slow tumescence, due to local muscle contraction, which may last for a few seconds and then slowly disappear. Characteristically, it appears in undernutrition and other wasting states, and an abundant, rich diet leads to its diminution (Smart, Macrae, Bastenie \& Gregoire, r948). It has been reported to respond to thiamine (Taylor \& Chhuttani, 1949) and has been described in conditions as diverse as physical exhaustion due to athletic contests and advanced tuberculosis. It may also be observed in apparently normal individuals.

\section{EXPERIMENTAL AND RESULTS}

The studies of the condition described below were mostly made in January and March 1949 in Berlin during the Russian blockade, or in September-October 1949 after it had been lifted and food had for 4 months passed into the city without restriction*.

\section{Association with leanness}

The subjects of the investigation were I05 men, all more or less lean, who were examined in January, March and October 1949. The reaction was elicited by holding the biceps muscle firmly between thumb and index finger and subjecting it to a single plucking pinch. The subject remained standing, his arm hanging comfortably at his side. In cases recorded as positive a contraction ring arose, after a slight delay, along the line of contact with the thumb and finger.

Table I shows that the incidence and degree of irritability remained more or less unchanged between January and March 1949. In September-October 1949 the sign was present in much less degree.

The relationship between skinfold thickness as measured by calipers and the duration of the myotatic response in the same subjects examined on three occasions is shown in Table 2. (Statistical analyses showed a high degree of significance; they have not been included here.)

There was in these men an obvious association between myotatic irritability and the amount of fat on the body; the thicker the layer of fat the shorter was the duration of the contraction ring. This was not because the plucking pinch was blanketed in the fatter subjects by the layer of fat that overlaid the muscle. The skinfold thickness over

\footnotetext{
* The food and nutritional situation in Berlin during the blockade has been reported by Berry, Cowin \& Magee (1951).
} 
the biceps was taken exactly at the level at which the myotatic stimulus was applied. The mean differences between those who showed a contraction ring and those who did not, in the first two examinations, are only of the order of $0.1-0.2 \mathrm{~mm}$ and, since a double layer of skin and fat is measured, the actual differences in interposing skin and fat are only half these values. It is very unlikely that such small differences could have affected the results. The increase in fat over the biceps recorded in October 1949 may Table I. Incidence of myotatic irritability in 105 men examined on three occasions during and after the blockade of Berlin in 1949

\begin{tabular}{|c|c|c|c|}
\hline \multirow[b]{2}{*}{ Time of examination } & \multicolumn{3}{|c|}{ No. of men showing } \\
\hline & No contraction & $\begin{array}{l}\text { Contraction } \\
\text { lasting } I-3 \text { sec } \\
\text { inclusive }\end{array}$ & $\begin{array}{c}\text { Contraction } \\
\text { lasting } 4 \text { sec } \\
\text { or over }\end{array}$ \\
\hline $\begin{array}{l}\text { During blockade: January } \\
\text { March }\end{array}$ & $\begin{array}{l}20 \\
22\end{array}$ & $\begin{array}{l}6 \mathrm{I} \\
58\end{array}$ & $\begin{array}{l}24 \\
25\end{array}$ \\
\hline After blockade: October & 44 & 49 & 12 \\
\hline
\end{tabular}

Table 2. Relation between thickness of subcutaneous tissues, as measured by calipers, and duration of myotatic contraction ring in 105 men on three occasions during and after the blockade of Berlin in 1949

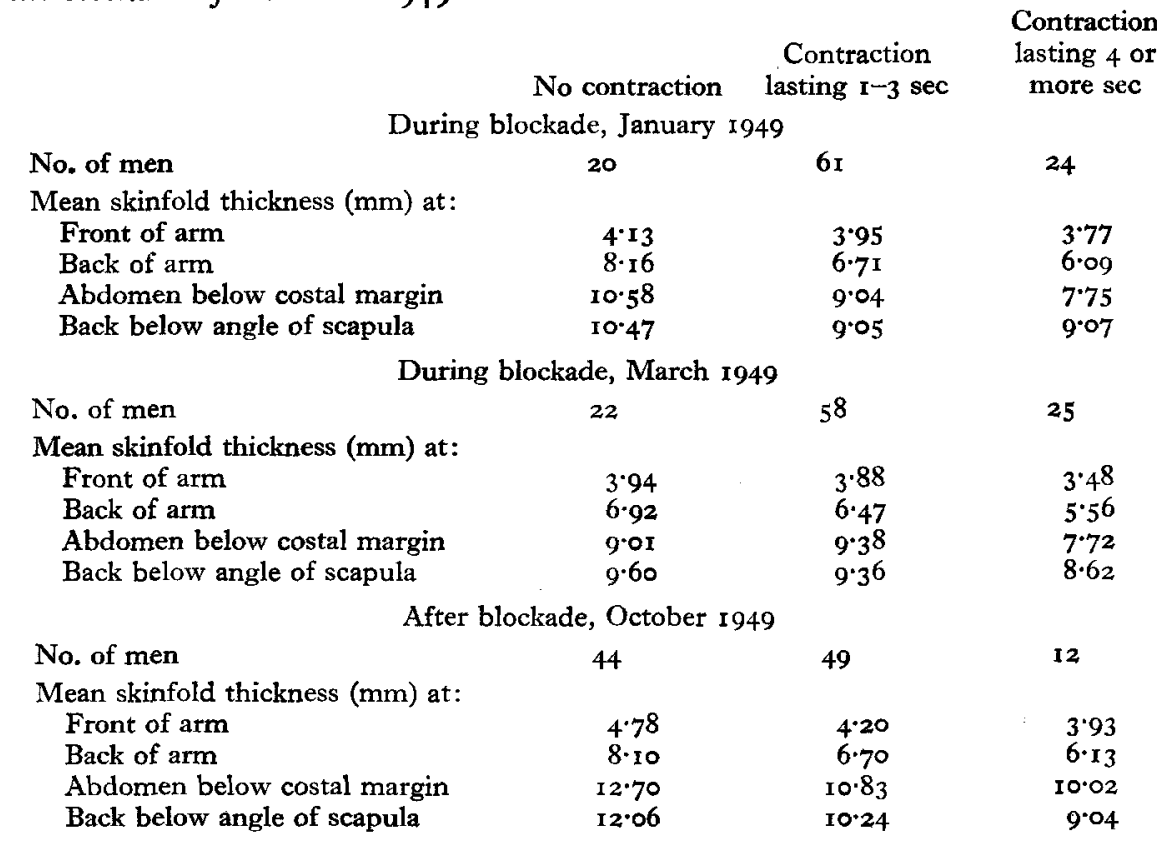

have been sufficient to blanket the stimulus, though the reduction in myotatic irritability is more likely to have been associated with the general improvement in nutrition that followed the lifting of the blockade.

\section{Thiamine administration}

Taylor \& Chhuttani's (1949) work was not published until October 1949, when, as already stated, myotatic irritability was on the decrease in Berlin. However, Dr Lottemöse of the Berlin Prison Medical Service kindly gave eight subjects, all of 
whom had some degree of myotatic irritability, $10 \mathrm{mg}$ thiamine by mouth daily for 23-100 days. By the end of the study the condition in six 'improved' and in two was 'worse'. Of seven controls the condition was unchanged in two, and 'improved' in two; in three it was 'worse' (Table 3 ).

The findings were compared, month by month, on the hypothesis that the degree of improvement was proportional to the number of seconds by which the duration of the contraction ring was reduced in comparison with the initial reading. The mean readings for each group are given in Table 3. For the ist month there was a considerable difference in favour of the thiamine-fed group, but it is not statistically significant. For the following 2 months there was little to choose between the two groups, and no comparison can be made for the last month. It is unfortunate that the experiment was carried out during a period when the men were increasing in weight, since, as already shown, the plumper the subject the less likely he is to show myotatic irritability. But the mean findings cannot legitimately be interpreted as showing an association between thiamine intake and myotatic irritability, and the fact that subject no. 7 , for example, belonging to the group given thiamine was 'worse' after prolonged and massive treatment than he was at the beginning, is proof that there was no constant specific relationship between the consumption of thiamine and the muscular condition.

\section{Site of excitation of the contraction}

Stolte (see de Jongh, I948) found in starving Dutch subjects that the contraction wave could still be elicited after blocking the brachial plexus and stellate ganglion with procaine, but that it was abolished after procaine infiltration of the muscle and perimysium, and suggested that the phenomenon was either of muscular or neuromuscular origin.

If the contraction ring could be produced after the motor-nerve endings had been paralysed with curare, the phenomenon must be muscular in origin. Through the kindness of Sir James Paterson Ross, Director of the Surgical Professorial Unit, St Bartholomew's Hospital, I was able to test patients resting in bed shortly after admission to the wards, and again under full anaesthesia. The findings are given in Table 4. Firstly, the effect of barbiturate induction with $\mathrm{N}_{2} \mathrm{O}$ plus trilene as anaesthetic (after morphine-hyoscine-atropine premedication) was tested in one subject (patient A) as this was a form of anaesthesia commonly used; the contraction ring, which had been easily elicited before operation, remained unchanged. Patients receiving this anaesthetic but who also required curare as part of their medication were therefore employed for the rest of the study. Patients B, C, D and E received from 20 to $30 \mathrm{mg}$ of $\mathrm{D}$-tubocurarine hydrochloride intravenously in the course of induction. A very marked degree of flaccidity resulted. The sign could still be elicited in every case. It is clear, therefore, that paralysis at the neuromuscular junction does not affect the condition; its abolition by procaine infiltration, in the Dutch study, must have been due to a direct effect upon the muscle.

It will be noted that in patients $B, C$ and $E$ there was an actual increase in the duration of the muscle response as a result of anaesthesia plus curare. This was apparently associated with the abolition of the minor degrees of muscular contraction 


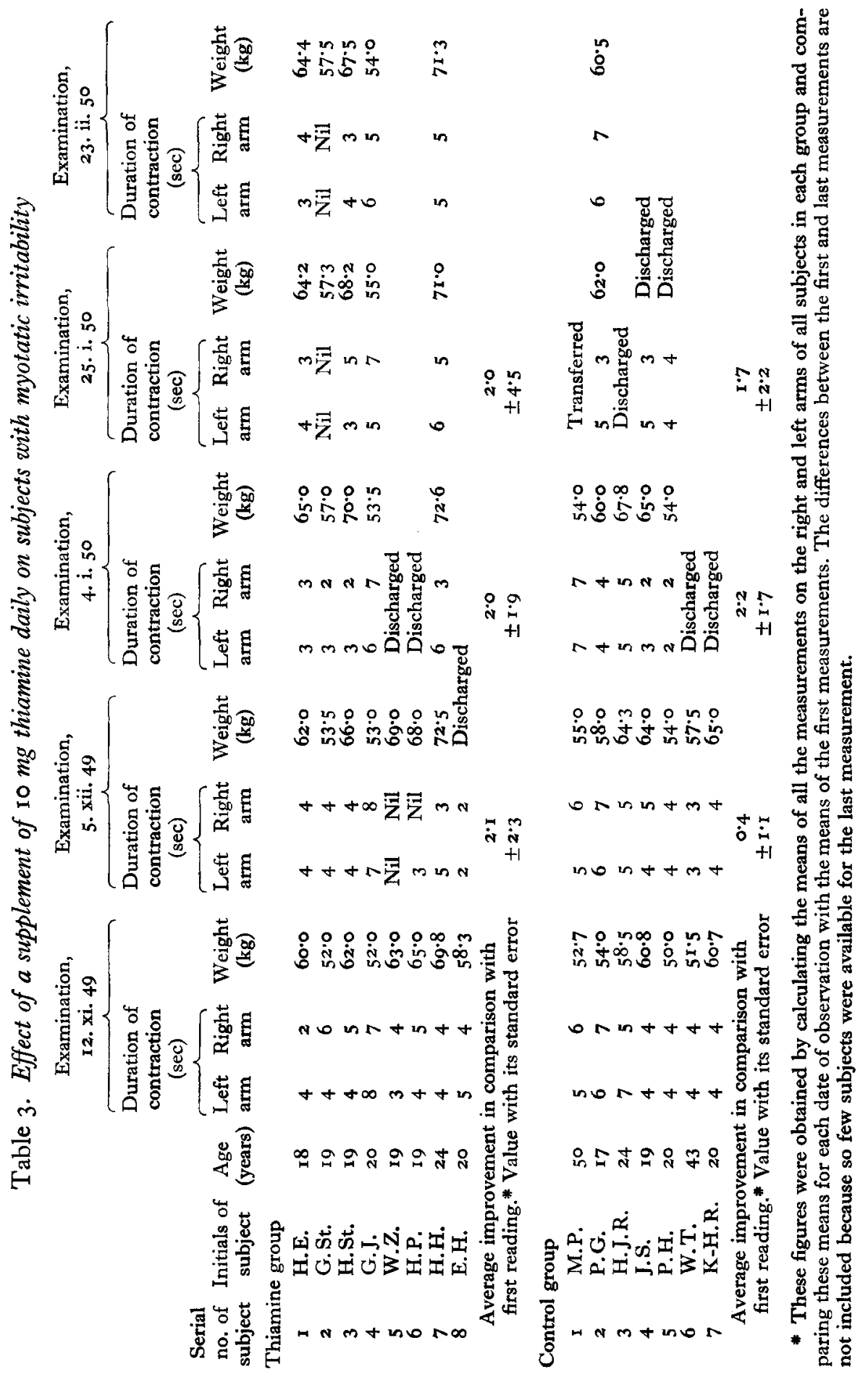


that are inseparable from the conscious state and are referred to by the clinician as muscle tone.

DISCUSSION

The persistence of the myotatic response despite curarization suggests that the mechanical stimulus operates at a site distal to the neuromuscular junction. Despite this finding, and the equivocal effect of thiamine administration, there is no essential disharmony with the report of Taylor \& Chhuttani (1949) that myotatic irritability may be associated with thiamine deficiency, for the effects of the latter are not restricted to nervous tissue. Flaccidity is common both to curarized muscle and to the muscle of beriberi.

Table 4. Effect of curarization upon duration of myotatic response by five patients in St Bartholomew's Hospital

$\begin{array}{ccccccc}\text { Patient } & \begin{array}{c}\text { Age } \\ \text { (years) }\end{array} & \begin{array}{c}\text { D-Tubocurarine } \\ \text { hydrochloride } \\ \text { given (mg) }\end{array} & \overbrace{\text { Right } \text { arm }}^{\text {Before anaesthesia }} & \text { Left arm } & \overbrace{\text { Right arm }}^{\text {Under anaesthesia }} & \text { Left arm } \\ \text { A } & 50 & \text { Nil } & 3.5 & 3.5 & 3.5 & 3.5 \\ \text { B } & 43 & 30 & <0.5 & 1.0 & 2.5 & 2.5 \\ \text { C } & 42 & 30 & <0.5 & 2.0 & 2.5 & 2.5 \\ \text { D } & 53 & 20 & 3.5 & 4.0 & 3.5 & 4.0 \\ \text { E } & 42 & 20 & 1.0 & 2.0 & 2.0 & 2.5\end{array}$

It is the author's impression that the extent to which the muscle becomes compressed by the plucking pinch, determines the extent of the myotatic response. Curare often enhances normal relaxation of muscle and, hence, its compressibility. In undernutrition of any degree the muscles become very soft to palpation; indeed in Berlin it was possible, simply by palpation, to predict those in whom the myotatic response would be greatest. The compressibility of muscle in undernutrition is greater than it is in the well-nourished, curarized, subject; and the duration of the myotatic response may be $8 \mathrm{sec}$ or more compared with the maximum of $4 \mathrm{sec}$ observed in the group of four curarized subjects. The effect of compression must be to thin and extend the muscle substance beneath the area involved, and release of pressure is apparently followed by a recoil, not merely to the point of 'normality', but beyond it. It is reasonable to suppose that the greater the original compression, the greater the magnitude of the recoil.

\section{SUMMARY}

I. A relationship is described between myotatic irritability and the amount of body fat in 105 men studied during and after the blockade of Berlin in 1949.

2. An equivocal response was observed to treatment with thiamine, in contrast to reports of its efficacy by other workers.

3. Persistence of the sign in curarized muscle showed that the site of its excitation was distal to the neuromuscular junction.

4. It is suggested that myotatic irritability is most marked when the muscle is easily compressed; undernutrition, curarization and thiamine deficiency have this in common that in all of these conditions the muscies are soft to touch and easily compressed. 
The material of this paper has been extracted from a thesis for the degree of M.D. Cambridge, I95I, and the author is grateful to the Regius Professor of Medicine for permission to publish it. The work of nutrition surveys in Berlin during the blockade was carried out with Drs H. E. Magee and P. J. Cowin of the Ministry of Health, whose help the author gratefully acknowledges.

\title{
REFERENCES
}

Berry, W. T. C., Cowin, P. J. \& Magee, H. E. (195I). Mon. Bull. Minist. Hlth Lab. Serv, 10, 155. de Jongh, C. L. (1948). In Malnutrition and Starvation in Western Netherlands, Part I, p. 97. [G. C. E. Burger, H. R. Sandstead and J. C. Drummond, editors.] The Hague: General State Printing Office.

Smart, G. A., Macrae, T. F., Bastenie, P. A. \& Gregoire, P. E. (1948). Brit. med. F. i, 40.

Taylor, G. F. \& Chhuttani, P. N. (1949). Brit. med. F. ii, 784 .

\section{The Absence of Anti-thyroid Properties for Rats in Two Types of Groundnut Oil in Common Use in Nigeria}

\author{
By JOYCE BUXTON, HILARY M. GRUNDY AND DAGMAR C. WILSON \\ Laboratory of Human Nutrition, University of Oxford \\ AND D. G. JAMISON \\ Laboratory of Physiology, University of Oxford
}

(Received 26 November I953)

Nigeria has the largest area of groundnut cultivation in the world and groundnut oil is commonly used as a food in the Northern Territory. There is a traditional method for the extraction of the oil by hand: the groundnuts are shelled, roasted and pounded to a paste; this paste is then kneaded with hot water and thoroughly mixed; the resulting sludge is put into a large pot, placed on a slow fire and kept constantly mixed. The floating oil is collected as it comes up to the surface. This operation is continued until no further oil is obtained and the residue in the pan becomes charred, giving the oil a strong flavour.

\section{EXPERIMENTAL}

Two samples of groundnut oil, one an indigenous hand-made oil and the other an unrefined crude oil, extracted by machine at Kano, Northern Nigeria, were sent to Oxford for testing their possible anti-thyroid properties in rats. Twenty-four male hooded rats, $7-8$ weeks old and weighing roo-1 $3^{2} \mathrm{~g}$, were fed on the following basic diet:

$\begin{array}{lrlr}\text { Sucrose } & 65 \% & \text { Groundnut oil } & 10 \% \\ \text { Casein (fat- and vitamin-free) } & 20 \% & \text { Salts } & 5 \%\end{array}$

